\title{
Clinical ketosis and standing behavior in transition cows
}

\section{A. J. Itle, J. M. Huzzey, D. M. Weary, and M. A. G. von Keyserlingk ${ }^{1}$}

Animal Welfare Program, Faculty of Land and Food Systems, University of British Columbia, 2357 Main Mall, Vancouver, BC, V6T 1Z4, Canada

\begin{abstract}
Ketosis is a common disease in dairy cattle, especially in the days after calving, and it is often undiagnosed. The objective of this study was to compare the standing behavior of dairy cows with and without ketosis during the days around calving to determine if changes in this behavior could be useful in the early identification of sick cows. Serum $\beta$-hydroxybutyrate (BHBA) was measured in 184 cows on a commercial dairy farm twice weekly from 2 to $21 \mathrm{~d}$ after calving. Standing behavior was measured from $7 \mathrm{~d}$ before calving to 21 d after calving using data loggers. Retrospectively, 15 cows with clinical ketosis (3 consecutive BHBA samples $>1.2 \mathrm{mmol} / \mathrm{L}$ and at least one sample of BHBA $>2.9 \mathrm{mmol} / \mathrm{L})$ were matched with 15 nonketotic cows $($ BHBA $<1.2 \mathrm{mmol} / \mathrm{L})$. Five periods were defined for the statistical analyses: wk -1 (d -7 to -1 ), d 0 (day of calving), wk +1 (d 1 to 7 ), wk +2 (d 8 to 14 ), and wk +3 (d 15 to 21 ). The first signs of clinical ketosis occurred $4.5 \pm 2.1 \mathrm{~d}$ after calving. Total daily standing time was longer for clinically ketotic cows compared with nonketotic cows during wk -1 (14.3 \pm 0.6 vs. 12.0 $\pm 0.7 \mathrm{~h} / \mathrm{d})$ and on $\mathrm{d} 0(17.2 \pm 0.9$ vs. $12.7 \pm 0.9 \mathrm{~h} / \mathrm{d})$ but did not differ during the other periods. Clinically ketotic cows exhibited fewer standing bouts compared with nonketotic cows on d 0 only (14.6 \pm 1.9 vs. 20.9 \pm 1.8 bouts/d). Average standing bout duration was also longer for clinically ketotic cows on d 0 compared with nonketotic cows [71.3 min/bout (CI: 59.3 to 85.5) vs. $35.8 \mathrm{~min} /$ bout (CI: 29.8 to 42.9 )] but was not different during the other periods. Differences in standing behavior in the week before and on the day of calving may be useful for the early detection of clinical ketosis in dairy cows.
\end{abstract}

Key words: $\beta$-hydroxybutyrate, disease, welfare, dairy cattle, health

\section{INTRODUCTION}

The transition from late gestation to early lactation has been associated with a high incidence of production

Received January 11, 2014

Accepted September 15, 2014.

${ }^{1}$ Corresponding author: nina@mail.ubc.ca diseases (Mulligan and Doherty, 2008), often related to the cow's inability to overcome negative energy balance. Cows compensate for rapid fetal growth in the final weeks of gestation and the onset of lactogenesis by mobilizing fat stores. All cows at this stage of lactation must rely, to some degree, on body reserves to meet the demands of lactation, but prolonged negative energy balance is often associated with ketosis (Ingvartsen, 2006). A poor adaptive response to negative energy balance and rapid lipolysis results in hyperketonemia, defined by overproduction of NEFA, and inadequate hepatic metabolism, resulting in accumulation of prominent ketone bodies: BHBA, acetoacetate, and acetone (Andersson, 1988; Grummer, 1993; Drackley, 1999).

Cows with high plasma concentrations of ketones around calving are at increased risk of disease (Duffield et al., 2009; Ospina et al., 2010a; Seifi et al., 2011), are more likely to be removed from the herd (McArt et al., 2012), are less likely to conceive at first service, and have lower milk production (Ospina et al., 2010b; McArt et al., 2012). The incidence of ketosis is estimated to range from 26 to $60 \%$ for subclinical ketosis (Simensen et al., 1990; Duffield et al., 1998; McArt et al., 2012) and from 2 to $15 \%$ for clinical ketosis (Duffield, 2000).

Despite the benefits of NEFA analysis for identifying prepartum cows at risk for ketosis (e.g., Ospina et al., 2010a; Seifi et al., 2011), no cowside test is available for this metabolite, limiting the practical use of this measure. Inexpensive cowside tests are available to detect acetoacetate and acetone in the urine (e.g., Ketostix Strip, Bayer, Leverkusen Germany) and BHBA in the milk (e.g., Keto-Test, Elanco Animal Health, SKK, Japan) and in the blood (e.g., Precision Xtra Meter, Abbott Diabetes Care, Abingdon, UK) (Carrier et al., 2004; Iwersen et al., 2009). These tests are useful for the diagnosis of ketosis in individual animals (Carrier et al., 2004) but are not validated for use before calving to assess energy balance (Oetzel, 2004; Ospina et al., 2010a), limiting their use for identifying cows at risk for this disease.

Recent work has demonstrated that changes in feeding and social behavior can be used in the early identification of cows at risk for ketosis. Goldhawk et al. (2009) reported that ketotic cows spent less time at the feed bunk and visited the feeder less often during the week before calving; for every 1-kg decrease in 
DMI, cows were 2.2 times more likely to develop ketosis. Those authors also found that cows that developed subclinical ketosis after calving had fewer competitive interactions at the feed bunk during peak feeding periods (Goldhawk et al., 2009). Although these behaviors show promise in identifying cows at risk for disease, no technologies are currently available that allow for practical monitoring of individual feeding and social behavior on commercial farms.

In contrast, there has been a growing interest in monitoring standing behavior for the early detection of illness in cattle. For example, Proudfoot et al. (2010) showed that standing behavior during transition differs for cows diagnosed with claw horn lesions in mid lactation. The use of electronic data loggers facilitates onfarm monitoring of this behavior (e.g., O'Driscoll et al., 2008; Ledgerwood et al., 2010). If changes in standing time could be used to identify cows at increased risk for ketosis, these cows could then be subjected to targeted testing of BHBA, which could expand the practicality of test application and improve ketosis detection. However, to our knowledge, no work to date has attempted to determine whether standing behavior could be used to predict ketosis in dairy cows. The objective of this study was to describe standing behavior of dairy cows with and without ketosis during the period around calving to determine whether changes in standing behavior precede clinical signs of disease.

\section{MATERIALS AND METHODS}

\section{Animals, Housing, and Management}

This study was conducted on a commercial dairy farm located in Whatcom County in Washington State between July and September 2012. Temperature averaged from 10.5 to $21^{\circ} \mathrm{C}$ with an average total rainfall of $2.1 \mathrm{~mm} / \mathrm{d}$ during the test period. All animal use was approved by the University of British Columbia's Animal Care Committee, according to the guidelines outlined by the Canadian Council of Animal Care (CCAC 2009).

In total, 184 Holstein dairy cows (62 primiparous and 122 multiparous cows) were monitored from approximately $7 \mathrm{~d}$ before calving until $21 \mathrm{~d}$ after calving. Cows were housed in 3 separate identical prepartum pens, each equipped with 118 headlocks $(76 \mathrm{~cm}$, center to center), $75 \mathrm{~m}$ of feed bunk space, $9 \mathrm{~m}$ of linear water space, and 100 stalls $(1.3 \times 2.4 \mathrm{~m})$ bedded with an average of 4.6 $\pm 2.5 \mathrm{~cm}$ (mean $\pm \mathrm{SD}$ ) layer of sawdust over a tire and concrete base once per week. Stocking ranged from 50 to 70 cows per pen $(61 \pm 10$; mean $\pm \mathrm{SD})$, which equated to an average stocking rate of 42 to $59 \%$ at the feed bunk and 50 to $70 \%$ in the freestalls. Animals were moved to a maternity pen bedded with deep straw when signs of imminent calving were visible and remained there for the first $24 \mathrm{~h}$ postpartum. After calving, all cows were moved to a single postpartum pen that contained 180 headlocks (76 cm center to center), $6.8 \mathrm{~m}$ of post-and-rail with hay access, $5 \mathrm{~m}$ of linear water space, and 173 stalls $(1.2 \times$ $2.2 \mathrm{~m}$ ) bedded with an average of $8.9 \pm 2.5 \mathrm{~cm}$ (mean \pm SD) of sawdust over a tire and concrete base twice per week. The stocking rate ranged from 136 to 163 cows per group (146 \pm 8 cows; mean $\pm \mathrm{SD}$ ), which equated to an average stocking rate of 75 to $90 \%$ at the feed bunk and 78 to $94 \%$ in the freestalls. Cows remained in the postpartum pen until they were approximately 21 to 25 DIM. Cows were removed from the pen for approximately $2 \mathrm{~h}$ for milking 3 times per day at approximately 0700, 1400, and $2100 \mathrm{~h}$ and fed a TMR once daily at approximately $0700 \mathrm{~h}$. Three weeks before calving, cows were fed a TMR consisting of $70 \%$ forage (corn silage, alfalfa hay, oat hay, straw) and 30\% concentrate mix (canola, distillers grains, ground corn) with a standard vitamin and mineral pack. Lactating cows were fed a TMR consisting of approximately $50 \%$ forage (corn silage, alfalfa hay, and oat hay) and 50\% concentrate (canola, cottonseed, distillers grains, and ground corn) with a standard vitamin and mineral pack and additional niacin, choline, yeast, and sodium bicarbonate.

\section{Standing Behavior}

Each cow was fitted with a data logger (Hobo Pendant G Acceleration Data Logger, Onset Computer Corp., Pocasset, MA) within a week of her expected calving date $(\mathrm{d}-7$ to -3$)$. Standing behavior was recorded using this Hobo data logger as described by Ito et al. (2009) and validated by Ledgerwood et al. (2010). The logger was wrapped in foam padding and attached to the lateral aspect of the distal hind cannon, proximal to the fetlock, with elastic wrap (Co-Flex, Andover Coated Products Inc., Salisbury, MA). It was oriented so that the $\mathrm{x}$-axis was parallel, the $\mathrm{y}$-axis was perpendicular, and the z-axis pointed away from the sagittal plane but parallel to the ground. At 1-min intervals, the logger recorded position relative to the orientation of the axes; this information was used to determine standing and lying times, number of bouts, and the duration of each bout. The loggers were removed and replaced between $\mathrm{d} 0$ and 3 after calving and then every $10 \mathrm{~d}$ thereafter until 21 DIM.

\section{Determination of Ketosis Status and Participation in Study}

After calving, blood samples were obtained from cows twice a week (Monday and Thursday) following 
the morning milking. Testing started at 2 DIM and occurred at 3- to 4-d intervals until 21 DIM. The twiceweekly testing scheme was chosen based on the results of a recent epidemiology paper on subclinical ketosis that reported the first confirmed positive BHBA test between 3 and 5 DIM and the median time to subclinical ketosis resolution as $5 \mathrm{~d}$ (McArt et al., 2012). It is recognized that cases lasting 2 to $3 \mathrm{~d}$ that did not coincide with a day of testing would have been missed, resulting in an underestimation of ketosis prevalence.

Blood was collected from the coccygeal vessel using a 1 -mL tuberculin syringe and 27 -gauge, $2.54-\mathrm{cm}$ needle within $3 \mathrm{~h}$ of the morning feeding, as cows returned from milking. Approximately $0.25 \mathrm{~mL}$ of blood was collected and immediately tested for BHBA concentration using the Precision Xtra meter (Abbott Laboratories, Alameda, CA; Iwersen et al., 2009). Additional details on blood collection and calibration and testing information associated with this procedure can be found in McArt et al. (2011).

Ketosis has been defined as elevated concentrations of circulating ketone bodies in the absence of clinical signs (Andersson, 1988). Cows with BHBA $<1.2 \mathrm{mmol} / \mathrm{L}$ throughout the entire 3 -wk data collection period were considered nonketotic. Ketosis diagnosis was based on a conservative definition of ketosis that required cows to have at least 3 consecutive samples of BHBA $\geq 1.2$ and $\leq 2.9 \mathrm{mmol} / \mathrm{L}$ to be considered subclinically ketotic and at least 3 consecutive samples of BHBA $\geq 1.2 \mathrm{mmol} / \mathrm{L}$ and at least one BHBA $>2.9 \mathrm{mmol} / \mathrm{L}$ to be considered clinically ketotic.

Although most studies have used a single measure of BHBA to evaluate ketosis (Goldhawk et al., 2009; McArt et al., 2012), others have incorporated factors such as serum calcium metabolites (Seifi et al., 2011), milk production and health (Duffield et al., 2009; Ospina et al., 2010b), and reproductive performance (Walsh et al., 2007; Ospina et al., 2010b; McArt et al., 2013) in their assessment. Previous research has shown a relationship between a single value above a predetermined concentration of BHBA and an increased risk of negative outcomes. However, the purpose of the current study was not to determine the optimum threshold for ketosis diagnosis but to describe changes in standing behavior between cows that were ketotic and cows that were not. A conservative case definition (3 consecutive positive tests) was therefore chosen. This definition eliminated cows that spontaneously recovered after a single ketosis event. Future work could consider other case definitions of ketosis.

Cows with BHBA $>2.9 \mathrm{mmol} / \mathrm{L}$ were drenched orally with $240 \mathrm{~mL}$ of propylene glycol (VetOne, distributed by MWI Veterinary Supply, Meridian, ID) and were administered 1,000 mL of dextrose 50\% (VetOne, MWI
Veterinary Supply) intravenously on the day of diagnosis by farm personnel; this treatment was only repeated if the cow tested positive (BHBA $>2.9 \mathrm{mmol} / \mathrm{L}$ ) on the following test day. Subclinically ketotic cows used in this study were not treated.

Following our classification criteria for ketosis status, and after excluding cows with malfunctioning data loggers, we were left with 4 cows with subclinical ketosis (1 primiparous, 3 multiparous) and 15 cows with clinical ketosis (3 primiparous, 12 multiparous). The number of cows with subclinical ketosis was deemed insufficient for meaningful statistical analyses, so all analysis focused only on cows with clinical ketosis. These 15 cows were paired with 15 nonketotic cows based on parity (average parity $2.6 \pm 1.4$ vs. $2.4 \pm 1.0$ for nonketotic and clinically ketotic cows, respectively) and the presence of any other disease condition (2 cows in each group were clinically lame and 3 other cows in each group were clinically metritic).

\section{Statistical Analyses}

All statistical analyses were performed using SAS software (version 9.3; SAS Institute Inc., Cary, NC) using cow $(\mathrm{n}=30)$ as the experimental unit. Five experimental periods were defined for analysis: wk -1 (d -7 to -1 relative to calving), d 0 (day of calving), wk +1 (d 1 to 7 after calving), wk +2 (d 8 to 14 ), and wk +3 (d 15 to 21 ). With the exception of $\mathrm{d} 0$, at least 3 complete days of data were required within each defined experimental period to generate a mean value for the period. Differences in standing time, standing bouts, and standing bout duration between health categories were analyzed using a mixed model, which included parity (primiparous or multiparous), period (wk -1 , d 0 , wk +1 , wk +2 , wk +3 ), health status (no ketosis, clinical ketosis), and the period $\times$ health status interaction. Period was considered a repeated measure and cow a random effect. An autoregressive covariance structure was used for these models based on best fit using the Bayesian information criteria in the Mixed procedure of SAS (SAS Institute Inc.). A logarithmic transformation was used to normalize standing bout duration; for this variable, least squares means and confidence intervals were back-transformed to obtain the geometric mean and $95 \%$ CI on the original scale.

To further explore the effect of time of day on standing behavior in clinically ketotic and nonketotic cows, average hourly standing time was determined based on data collected during the week before $(\mathrm{wk}-1)$ and the week after $(\mathrm{wk}+1)$ calving. Differences among health categories in the distribution of 24-h standing times were analyzed with a mixed model that used a heterogeneous autoregressive covariance structure. Cow 
was treated as a random effect and hour as a repeated measure. The model tested fixed effects of parity, hour, and health status, and the health status by hour interaction.

\section{RESULTS}

Of the clinically ketotic cows enrolled in the study, $20 \%$ recovered (BHBA $<1.2 \mathrm{mmol} / \mathrm{L}$ ) by the end of the test period. Of the cows that recovered from ketosis, the average time from first positive test until a BHBA test $<1.2 \mathrm{mmol} / \mathrm{L}$ was $9.0 \pm 4.4 \mathrm{~d}$.

Cows with clinical ketosis tended to stand longer than nonketotic cows throughout the entire study period $(15.0 \pm 0.4$ vs. $13.9 \pm 0.5 \mathrm{~h} / \mathrm{d} ; P=0.06)$; this response was driven by longer standing times among clinically ketotic cows during the week before and on the day of calving (Figure 1A; health status $\times$ period interaction: $P<0.005)$. During wk -1 , cows with clinical ketosis stood for $2.4 \mathrm{~h} / \mathrm{d}$ longer than nonketotic cows; on the day of calving, cows with clinical ketosis stood for $4.5 \mathrm{~h} / \mathrm{d}$ longer than nonketotic cows. After calving, standing behavior did not differ between the 2 health categories. We observed no effect of parity on standing time and no parity $\times$ health status interaction.

We detected a significant period $\times$ health status interaction for standing bouts $(P=0.02)$. On d 0 , cows that were diagnosed with clinical ketosis had 6.3 fewer standing bouts than their nonketotic counterparts (14.6 \pm 1.9 vs. $20.9 \pm 1.8$ bouts/d; Figure 1B), but health status had no effect during any other period. Overall, primiparous cows had more standing bouts than multiparous cows $(13.4 \pm 1.1$ vs. $10.3 \pm 0.6$ bouts $/ \mathrm{d} ; P$ $=0.02$ ), but we observed no parity $\times$ health status interaction.

A period $\times$ health status interaction was observed for standing bout duration $(P=0.03)$. Average bout duration on d 0 was $71.3 \mathrm{~min} /$ bout (CI: 59.3 to 85.5 ) for nonketotic cows compared with $35.8 \mathrm{~min} /$ bout (CI: 29.8 to 42.9 ) for those with ketosis; Figure 1C); no differences between the health categories were detected in any other period. Primiparous cows had shorter average standing bout durations than multiparous cows [64.9 $\mathrm{min} /$ bout (CI: 56.1 to 75.1 ) vs. $94.6 \mathrm{~min} /$ bout (CI: 88.3 to 101.3 ); $P=0.03$ ], but no parity by health status interaction was found.

The diurnal analysis of standing time during wk -1 revealed an effect of health status $(P=0.002)$ but no standing time $\times$ hour interaction $(P=0.20)$, indicating that across all hours of the day, clinically ketotic cows stood for longer than nonketotic cows (Figure $2 \mathrm{~A})$. During wk +1 there was a health status $\times$ hour interaction $(P=0.003)$, driven by more pronounced differences between 1700 and $2200 \mathrm{~h}$ (Figure 2B).
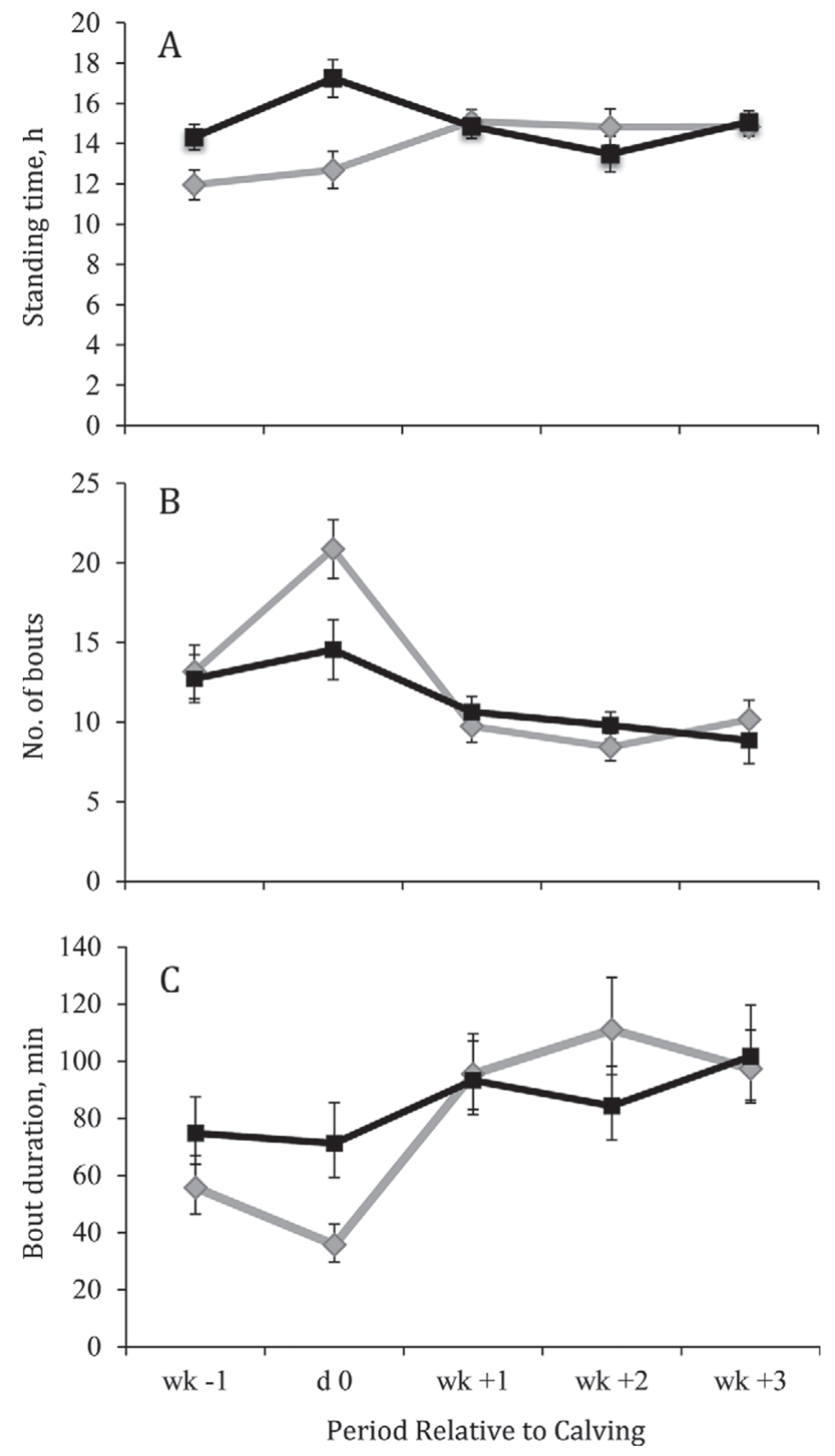

Figure 1. (A) Least squares means $( \pm \mathrm{SE})$ standing time, (B) least squares means $( \pm \mathrm{SE})$ number of standing bouts, and $(\mathrm{C})$ back-transformed least squares means $( \pm 95 \%$ CI $)$ of standing bout duration, for Holstein dairy cows that were nonketotic (gray diamonds, $\mathrm{n}=15$ ) or clinically ketotic (black squares, $\mathrm{n}=15$ ) during 5 periods around calving ( $\mathrm{wk}-1$, day of calving, wk +1 , wk +2 , wk +3 ).

\section{DISCUSSION}

The results of current study indicate that differences in standing behavior in the week before calving and on the day of calving show promise for the early detection of clinical ketosis in dairy cows. Cows that were later diagnosed with clinical ketosis stood $20 \%$ longer during the week before calving and $35 \%$ longer on the day of calving compared with nonketotic cows. 

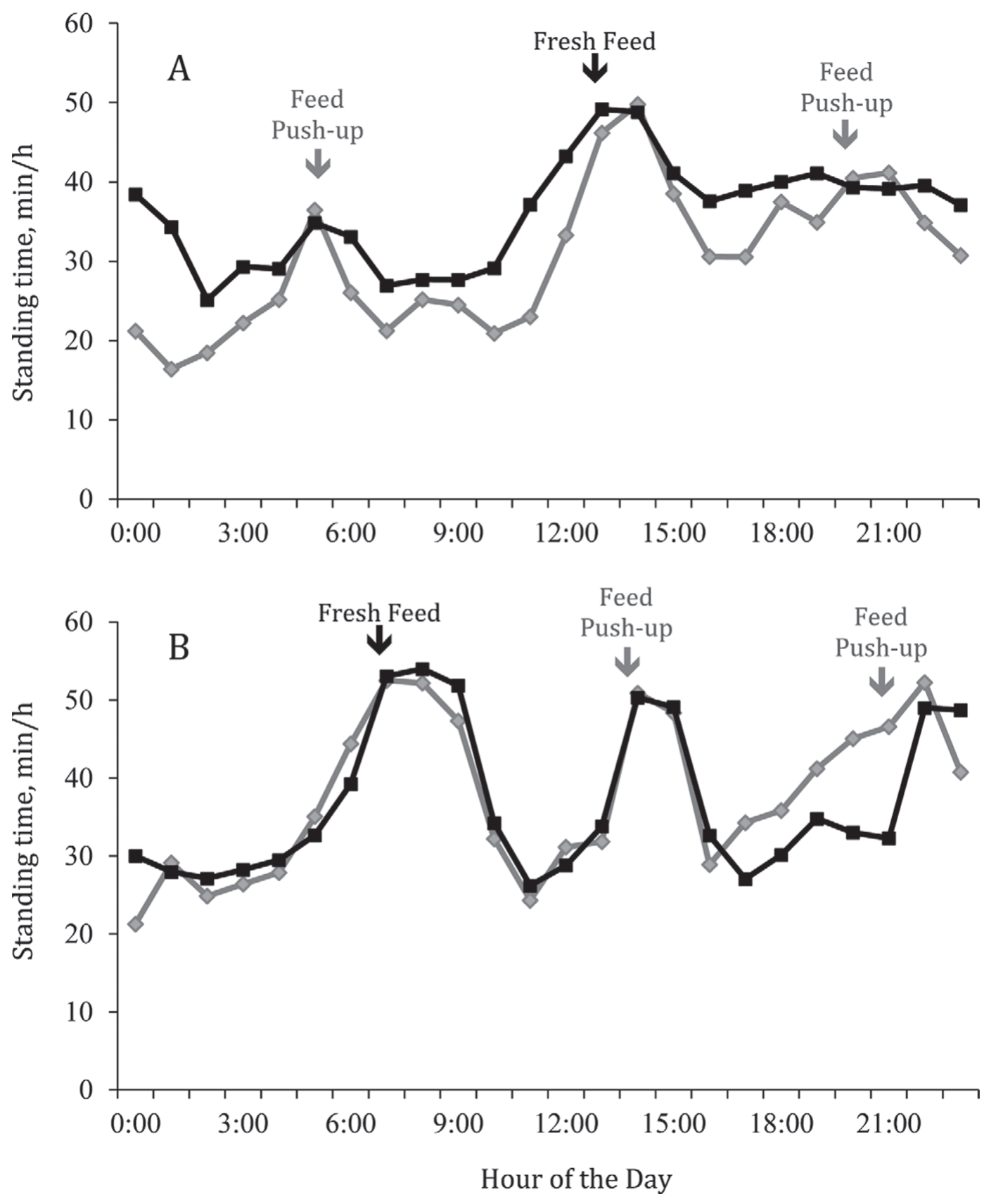

Figure 2. Diurnal pattern of hourly standing time (least squares means $\pm \mathrm{SE}$ ) for Holstein dairy cows that were nonketotic (gray diamonds, $\mathrm{n}=15)$ or clinically ketotic (black squares, $\mathrm{n}=15)$ during the week before calving $(\mathrm{d}-7$ to $-2 ; \mathrm{A})$ and the week after calving $(\mathrm{d}+2$ to +7 ; $\mathrm{B})$.

Variation in standing times by clinically ketotic cows in the week before calving may be a consequence of differences in social rank or competition. Previous work has shown that subordinate cows are more likely to engage in avoidance behavior in response to social confrontations (Huzzey et al., 2006; Goldhawk et al., 2009; Proudfoot et al., 2009). Social factors may be especially important for cows housed in freestall barns where they have to compete for access to resources (Val-Laillet et al., 2008). Even though cows in the current study were understocked, ketotic cows are known to behave in a subordinate fashion, potentially increasing standing time as they wait to access feed (Huzzey et al., 2006; Goldhawk et al., 2009). We expect that the differences reported here would be more pronounced on farms using higher stocking densities.

Work done a decade ago by Edwards and Tozer (2004) summarized the walking activity of dairy cows 
in 3 Florida herds. Those authors found that cows diagnosed with ketosis at $10 \pm 8$ DIM had lower walking activity in the first 14 DIM. The authors speculated that the difference in activity was due to sick cows having lower appetites, spending less time at the feed bunk, and spending more time lying down; unfortunately, standing times were not measured. Our results, showing a decreasing trend in standing time for ketotic cows after calving, are consistent with these earlier results.

In addition to increased standing times in the week before calving, cows that developed clinical ketosis in the days following calving had fewer standing bouts and longer bout duration on d 0 compared with nonketotic cows. Previous work has shown that cows stand longer and have more standing bouts (Huzzey et al., 2005; Jensen, 2012) on the day of calving, presumably due to discomfort associated with parturition (Huzzey et al., 2005). Previous work has shown that ketosis is a progressive disease associated with gradual changes in NEFA and blood glucose starting in the prepartum period, progressing to varying degrees of hyperketonemia (Bobe et al., 2004). Cows experiencing ketosis may also feel ill (see review by Weary et al., 2009) and be less willing to engage in behaviors that are energetically expensive (e.g., changing position from lying to standing; Susenbeth et al., 2004). This may explain, at least in part, the differences in standing bouts and longer bout durations observed by the clinically ketotic cows compared with the nonketotic cows in the current study. Other energetically expensive behaviors that may change in response to lethargy induced by ketosis include competitive behaviors associated with gaining access to resources such as feed and lying space, although this could not be measured in the current study.

The current results suggest that differences in standing time associated with ketosis are more prominent at certain times of the day. The diurnal pattern of standing behavior is influenced by the time of fresh feed delivery, feed pushup, and milking (see review by von Keyserlingk and Weary, 2010). Cows with and without ketosis were similar in standing patterns in the week before calving and for the majority of the day postcalving, but clinically ketotic cows spent less time standing in the late afternoon and evening hours. At this time of day, worker activity on the farm is likely reduced and management practices such as regrouping are less likely to occur. We speculate that the increased lying time by clinically ketotic cows during these hours was indicative of lethargy and depression-classic sickness behaviors (Hart, 1988) in response to feeling ill; cows may be less willing to express these behaviors earlier in the day due to management disruptions that can occur on working farms.
Existing methods to detect ketosis are typically focused on identifying cows that are already sick. The approach described in the current paper focused on identifying cows at risk for ketosis. The results indicate that changes in standing behavior can be detected before changes in blood chemistry.

\section{ACKNOWLEDGMENTS}

We are grateful to the owners and barn staff of the dairy farm in Whatcom County, Washington, for allowing us to run this study. This research was funded by a Natural Science and Engineering Discovery Grant (Ottawa, Canada) awarded to MVK.

\section{REFERENCES}

Andersson, L. 1988. Subclinical ketosis in dairy cows. Vet. Clin. North Am. Food Anim. Pract. 4:233-251.

Bobe, G., J. W. Young, and D. C. Beitz. 2004. Invited review: Pathology, etiology, prevention and treatment of fatty liver in dairy cows. J. Dairy Sci. 87:3105-3124.

Canadian Council on Animal Care (CCAC). 2009. CCAC Guidelines on: the Care and Use of Farm Animals in Research, Teaching and Testing. Ottawa, ON, Canada.

Carrier, J., S. Stewart, S. Godden, J. Fetrow, and P. Rapnicki. 2004. Evaluation and use of three cowside tests for detection of subclinical ketosis in early postpartum cows. J. Dairy Sci. 87:3725-3735.

Drackley, J. K. 1999. Biology of dairy cows during the transition period: The final frontier? J. Dairy Sci. 82:2259-2273.

Duffield, T. 2000. Subclinical ketosis in lactating dairy cattle. Vet. Clin. North Am. Food Anim. Pract. 16:231-253.

Duffield, T. F., K. D. Lissemore, B. W. McBride, and K. E. Leslie. 2009. Impact of hyperketonemia in early lactation dairy cows on health and production. J. Dairy Sci. 92:571-580.

Duffield, T. F., D. Sandals, K. E. Leslie, K. Lissemore, B. W. McBride, J. H. Lumsden, P. Dick, and R. Bagg. 1998. Efficacy of monensin for prevention of subclinical ketosis in lactating dairy cows. J. Dairy Sci. 81:2866-2873.

Edwards, J. L., and P. R. Tozer. 2004. Using activity and milk yield as predictors of fresh cow disorders. J. Dairy Sci. 87:524-531.

Goldhawk, C., N. Chapinal, D. M. Viera, D. M. Weary, and M. A. G. von Keyserlingk. 2009. Prepartum feeding behavior is an early indicator of subclinical ketosis. J. Dairy Sci. 92:4971-4977.

Grummer, R. R. 1993. Etiology of lipid-related metabolic disorders in periparturient dairy cows. J. Dairy Sci. 76:3882-3896.

Hart, B. L. 1988. Biological basis of the behavior of sick animals. Neurosci. Biobehav. Rev. 12:123-137.

Huzzey, J. M., T. J. DeVries, P. Valois, and M. A. G. von Keyserlingk. 2006. Stocking density and feed barrier design affect the feeding and social behavior of dairy cattle. J. Dairy Sci. 89:126-133.

Huzzey, J. M., M. A. G. von Keyserlingk, and D. M. Weary. 2005. Changes in feeding, drinking, and standing behavior of dairy cows during the transition period. J. Dairy Sci. 88:2454-2461.

Ingvartsen, K. L. 2006. Feeding- and management-related diseases in the transition cow: Physiological adaptations around calving and strategies to reduce feeding-related diseases. Anim. Feed Sci. Technol. 126:175-213.

Ito, K., D. M. Weary, and M. A. G. von Keyserlingk. 2009. Lying behavior: Assessing within- and between-herd variation in freestallhoused dairy cows. J. Dairy Sci. 92:4412-4420.

Iwersen, M., U. Falkenberg, R. Voigtsberger, D. Forderung, and W. Heuwieser. 2009. Evaluation of an electronic cowside test to detect subclinical ketosis in dairy cows. J. Dairy Sci. 92:2618-2624.

Jensen, M. B. 2012. Behaviour around the time of calving in dairy cows. Appl. Anim. Behav. Sci. 139:195-202. 
Ledgerwood, D. N., C. Winckler, and C. B. Tucker. 2010. Evaluation of data loggers, sampling intervals, and editing techniques for measuring the lying behavior of dairy cattle. J. Dairy Sci. 93:5129-5139.

McArt, J. A. A., D. V. Nydam, and G. R. Oetzel. 2012. Epidemiology of subclinical ketosis in early lactation dairy cattle. J. Dairy Sci. 95:5056-5066.

McArt, J. A. A., D. V. Nydam, and G. R. Oetzel. 2013. Dry period and parturient predictors of early lactation hyperketonemia in dairy cattle. J. Dairy Sci. 96:198-209.

McArt, J. A. A., D. V. Nydam, P. A. Ospina, and G. R. Oetzel. 2011. A field trial on the effect of propylene glycol on milk yield and resolution of ketosis in fresh cows diagnosed with subclinical ketosis. J. Dairy Sci. 94:6011-6020.

Mulligan, F. J., and M. L. Doherty. 2008. Production diseases of the transition cow. Vet. J. 176:3-9.

O'Driscoll, K. O., L. Boyle, and A. Hanlon. 2008. A brief note on the validation of a system for recording lying behavior in dairy cows. Appl. Anim. Behav. Sci. 111:195-200.

Oetzel, G. R. 2004. Monitoring and testing dairy herds for metabolic disease. Vet. Clin. North Am. Food Anim. Pract. 20:651-674.

Ospina, P. A., D. V. Nydam, T. Stokol, and T. R. Overton. 2010a. Evaluation of nonesterified fatty acids and $\beta$-hydroxybutyrate in transition dairy cattle in the northeastern United States: Critical thresholds for prediction of clinical disease. J. Dairy Sci. 93:546554.

Ospina, P. A., D. V. Nydam, T. Stokol, and T. R. Overton. 2010b. Associations of elevated nonesterified fatty acids and $\beta$-hydroxybutyrate concentrations with early lactation reproductive performance and milk production in transition dairy cattle in the northeastern United States. J. Dairy Sci. 93:1596-1603.
Proudfoot, K. L., D. M. Veira, D. M. Weary, and M. A. G. von Keyserlingk. 2009. Competition at the feed bunk during transition changes the feeding, standing and social behavior of Holstein dairy cows. J. Dairy Sci. 92:3116-3123.

Proudfoot, K. L., D. M. Weary, and M. A. G. von Keyserlingk. 2010. Behavior during transition differs for cows diagnosed with claw horn lesions in mid lactation. J. Dairy Sci. 93:3970-3978.

Seifi, H. A., S. J. LeBlanc, K. E. Leslie, and T. F. Duffield. 2011. Metabolic predictors of post-partum disease and culling risk in dairy cattle. Vet. J. 188:216-220.

Simensen, E., K. Halse, P. Gillund, and B. Lutnaes. 1990. Ketosis treatment and milk yield in dairy cows related to milk acetoacetate levels. Acta Vet. Scand. 31:433-440.

Susenbeth, A., T. Dickel, K.-H. Sudekum, W. Drochner, and H. Steinga. 2004. Energy requirements of cattle for standing and for ingestion, established by a ruminal emptying technique. J. Anim. Sci. 82:129-136.

Val-Laillet, D., D. M. Veira, and M. A. G. von Keyserlingk. 2008. Short communication: Dominance in freestall-housed dairy cattle is dependent upon resource. J. Dairy Sci. 91:3922-3926.

von Keyserlingk, M. A. G., and D. M. Weary. 2010. Feeding behaviour of dairy cattle: Measures and applications. Can. J. Anim. Sci. 90:303-309.

Walsh, R. B., J. S. Walton, D. F. Kelton, S. J. LeBlanc, K. E. Leslie, and T. F. Duffield. 2007. The effect of subclinical ketosis in early lactation on reproductive performance of postpartum dairy cows. J. Dairy Sci. 90:2788-2796.

Weary, D. M., J. M. Huzzey, and M. A. G. von Keyserlingk. 2009. Board-invited review: Using behaviour to predict and identify il health in animals. J. Anim. Sci. 87:770-777. 